\title{
Attainment of Sustainability through Green Auditing: A Case Study of Musaliar Institute, Pathanamthitta
}

\author{
Shamila Habeeb ${ }^{1}$, Adharsh $\mathrm{A}^{2}$, Anju Aji ${ }^{3}$, Aswathy Shaji ${ }^{4}$, Noufal $\mathrm{N}^{5}$ \\ ${ }^{1}$ Asst. Professor, ${ }^{2345}$ Student \\ Civil Department, Musaliar College of Engineering \& Technology, Pathanamthitta.
}

\begin{abstract}
Green auditing is a management tool used to identify the environmental impacts and assessment of problems with suitable corrections. In scenario people are not caring of nature, they are directly or indirectly damaging the environment and it causes problems like global warming, difficulties in maintaining ozone layers, air pollution, water pollution etc. Green auditing is the most efficient and sustainable way to solve environmental impacts. Musaliar Institute, Pathanamthitta is comfortably located in an ecologically sensitive area, a small change in its ecology can lead to high amount of damages. For our campus, the target areas for Green auditing are energy management, waste management, water management, biodiversity mapping and carbon emission evaluation. The Carbon emission evaluation is an important process that involves the amount of carbon dioxide emitted at the campus. Strong green audit process can help to achieve sustainable institution.
\end{abstract}

Keywords- Sustainability, Water consumption, Energy consumption, Energy conservation, Carbon emission, Emission factor, Coli forms, E-coli, Biodiversity.

\section{INTRODUCTION}

The Green auditing involves collection, collation, analysis, interpretation and presentation of information which is used to assess performance against a set of requirements or targets related to environmental issues. For the analysis of this auditing no protocol, only basic methods of techniques is used. It also aims to analyze the environmental practices within and outside of the concerned sites, which will have an impact on the eco-friendly ambience. Green audit can also used in college/ institutions to determine how and where they are using the most energy or water or any other resources, the college can then consider how to implement changes and make savings. It can also be used to determine the type and volume of waste, which can be used for a recycling project or to improve waste minimization plan. It can create health consciousness and promote environmental awareness, values and ethics. It provides staff and students better understanding of Green impact on campus. For the evaluation of green auditing on a particular target, it is mainly classified in to three stages namely Pre-auditing stage, Auditing stage, and Post auditing stage for the step by step analysis of impacts on the environment.

\section{OBJECTIVES}

$>$ To ensure development along with safeguarding the environment.

$>$ To provide basis for improved sustainability.
$>$ More efficient resource management.

$>$ To create a green campus.

$>$ To enable waste management.

$>$ To secure the quality of water used.

$>$ Recognize the cost effective methods through waste minimizing and managing.

$>$ To secure the environment and cut down the threats posted to human health.

$>$ To provide how much carbon is emitted in the institution.

\section{SCOPE}

The scope of the green audit is very flexible depending up on the needs of an institution. It involves the inspection of an institute to assess the total environmental impact of its activities or a particular product or a process. Therefore, the scope of Green Audit can be listed as below:

$>$ Measuring key environmental parameters.

$>$ Analyzing raw \& test data.

$>$ Communicating with institutional authorities, staffs, students and workers.

$>$ Examining policies, internal records, reports relating to environmental aspects.

\section{ABOUT THE INSTITUTION}

Musaliar College of Engineering and Technology is a NAAC (National Assessment and Accreditation Council) Accredited Engineering and Management Institut0ion under the renowned Musaliar Education Trust. The Musaliar Education Trust which is a charitable trust was founded in the year 2001 by a group of well settled educationalists and technocrats having vast experience in the educational and technical fields. The College is comfortably located in a sprawling campus within the town limits of Pathanamthitta Municipality. Located along the Pathanamthitta - Malayalapuzha District Highway, the campus is easily accessible by road (about 10 Minutes drive from the Civil Station, Pathanamthitta). Frequent private and KSRTC buses provide cheap and easy accessibility to the campus. The college campus spread over a sprawling 15 acres of land consists of many well designed multi-storied buildings which have all the state of the art infrastructural facilities like Computer Centers, Electronics and Digital Laboratories, well equipped Mechanical and Electrical Workshops, Survey Lab and a well furnished Library with more than 10,000 recent volumes of engineering books and journals. The class rooms, drawing halls, seminar halls etc. are spacious and 
well designed to meet international standards for the academic activities.

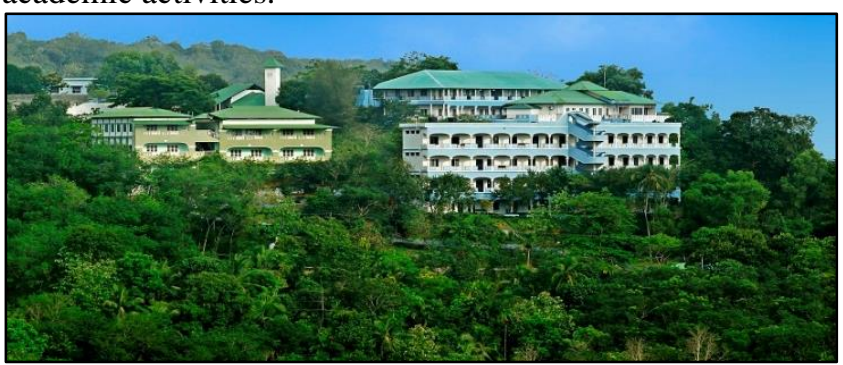

Fig. 1 Greenery of Musaliar Institute

\section{METHODOLOGY}

\section{A General}

The methodology includes data collection from each target areas, preparation and filling up of questionnaire, observation and review of the documentation, interviewing key persons and data analysis, measurements and recommendations. Some data have also been taken from the students, teaching staffs, office staffs, and various departments of the college

\section{B Target Areas of Auditing}

1) Water management: This involves the water sources, water consumption, irrigation, rain water, appliances and a well authorized water test.

2) Energy management: This involves the energy sources, energy consumption, energy inspection, lighting, cooling, computer appliances and vehicles.

3) Health management: It is the systematic analysis of the quality of healthcare which includes common diseases in the campus, surveying the symptoms, behaviour of health and non-health determinants.

4) Waste management: This involves the waste production and disposal, plastic waste, paper waste, food waste, quantity of waste and recycling. This is an essential management study to minimize the waste in the college for sustainability.

5) Biodiversity mapping: This involves the data collection of plants and animal species present in the college campus. The data collection involves detailed number of different plant species and types of animals by inspecting the college.

6) Carbon emission: This involves the amount of carbon dioxide emission at the campus and suggests suitable solutions to reduce the carbon emission in the campus.

\section{OBSERVATIONS AND RESULTS}

\section{A Water Audit}

The main source of water in the institute is a pond located at Kumbazha. It is about $2 \mathrm{~km}$ away from the college campus. Daily 100000 liter of water is collected from the pond and store in a tank having a capacity of 350000 liter for purification process. There is five tanks are located in different areas of campus for distribution purpose. From the 150000 liter water tank, the water is supply to ladies hostel and boy's hostel. From the 100000 liter water tank located near Engineering College, the ground water is distributed to MBA College. The water purification process is carried out in a 350000 liter water tank.

\section{1) Water quality analysis}

For the water quality analysis different tests are conducted on various water samples collected from different spots of the institute. The water samples collected are sample from main source (pond), sample from water tank and sample from cooler. The various testes conducted for the quality analysis are ph, turbidity, electrical conductivity, total dissolved solid, acidity, alkalinity, hardness, residual chlorine, and basic characteristics of the water.

TABLE I. WATER QUALITY ANALYSIS OF POND WATER

\begin{tabular}{|c|c|c|c|c|}
\hline $\begin{array}{c}\text { Serial } \\
\text { No. }\end{array}$ & Characteristics & Units & $\begin{array}{c}\text { Desirable } \\
\text { Limits }\end{array}$ & $\begin{array}{c}\text { Actual } \\
\text { Contents }\end{array}$ \\
\hline 1 & Turbidity & NTU & 1 & 4.8 \\
\hline 2 & $\mathrm{pH}$ & & 6.5 to 8.5 & 6.8 \\
\hline 3 & $\begin{array}{c}\text { Electrical } \\
\text { conductivity }\end{array}$ & Mhos/cm & & 76 \\
\hline 4 & Acidity & $\mathrm{mg} /$ /itre & & 10 \\
\hline 5 & Alkalinity (Total) & $\mathrm{mg}$ /litre & 200 & 20 \\
\hline 6 & Sulphates & $\mathrm{mg} /$ litre & 200 & 1.4 \\
\hline 7 & $\begin{array}{l}\text { Total dissolved } \\
\text { solids }\end{array}$ & $\mathrm{mg} /$ litre & 500 & 41 \\
\hline 8 & Total hardness & $\mathrm{mg} /$ litre & 200 & 20 \\
\hline 9 & Calcium & $\mathrm{mg}$ /litre & 75 & 4 \\
\hline 10 & Magnesium & $\mathrm{mg} /$ litre & 30 & 2.43 \\
\hline 11 & Chloride & $\mathrm{mg} /$ /itre & 250 & 12 \\
\hline 12 & Fluoride & $\mathrm{mg} /$ /itre & 1 & BDL \\
\hline 13 & Iron & $\mathrm{mg} /$ litre & 1 & 0.8 \\
\hline 14 & Nitrate & $\mathrm{mg} /$ litre & 45 & BDL \\
\hline 15 & Residual Chlorine & $\mathrm{mg} /$ litre & 0.2 & Nil \\
\hline 16 & Coli forms & $\begin{array}{c}\text { No. of } \\
\text { coli } \\
\text { forms/ } \\
100 \mathrm{ml}\end{array}$ & 0 & 1100 \\
\hline 17 & E-Coli & $\begin{array}{c}\text { No. of } \\
\text { coli } \\
\text { forms/ } \\
100 \mathrm{ml}\end{array}$ & 0 & 15 \\
\hline
\end{tabular}

TABLE II. WATER QUALITY ANALYSIS OF WATER TANK

\begin{tabular}{|c|c|c|c|c|}
\hline $\begin{array}{l}\text { Serial } \\
\text { No. }\end{array}$ & Characteristics & Units & $\begin{array}{c}\text { Desirable } \\
\text { Limits }\end{array}$ & $\begin{array}{c}\text { Actual } \\
\text { Contents }\end{array}$ \\
\hline 1 & Turbidity & NTU & 1 & BDL \\
\hline 2 & $\mathrm{Ph}$ & & 6.5 to 8.5 & 6.93 \\
\hline 3 & $\begin{array}{c}\text { Electrical } \\
\text { conductivity }\end{array}$ & Mhos/cm & & 78 \\
\hline 4 & Acidity & mg/litre & & 10 \\
\hline 5 & Alkalinity (Total) & $\mathrm{mg} /$ litre & 200 & 12 \\
\hline 6 & Sulphates & mg/litre & 200 & 0.4 \\
\hline 7 & $\begin{array}{l}\text { Total dissolved } \\
\text { solids }\end{array}$ & $\mathrm{mg} /$ litre & 500 & 44 \\
\hline 8 & Total hardness & $\mathrm{mg} /$ litre & 200 & 30 \\
\hline 9 & Calcium & $\mathrm{mg} /$ litre & 75 & 9.6 \\
\hline 10 & Magnesium & $\mathrm{mg} /$ litre & 30 & 1.46 \\
\hline 11 & Chloride & $\mathrm{mg} /$ litre & 250 & 14 \\
\hline 12 & Fluoride & $\mathrm{mg} /$ litre & 1 & 0.07 \\
\hline 13 & Iron & $\mathrm{mg} /$ litre & 1 & 0.32 \\
\hline 14 & Nitrate & $\mathrm{mg} /$ litre & 45 & BDL \\
\hline 15 & Residual Chlorine & $\mathrm{mg} /$ litre & 0.2 & 0 \\
\hline 16 & Coli forms & $\begin{array}{c}\text { No. of } \\
\text { coli } \\
\text { forms/ } \\
100 \mathrm{ml}\end{array}$ & 0 & 44 \\
\hline 17 & E-Coli & $\begin{array}{l}\text { No. of } \\
\text { coli } \\
\text { forms/ } \\
100 \mathrm{ml}\end{array}$ & 0 & 3 \\
\hline
\end{tabular}


TABLE III. WATER QUALITY ANALYSIS OF COOLER

\begin{tabular}{|c|c|c|c|c|}
\hline $\begin{array}{c}\text { Serial } \\
\text { No. }\end{array}$ & Characteristics & Units & $\begin{array}{c}\text { Desirable } \\
\text { Limits }\end{array}$ & $\begin{array}{c}\text { Actual } \\
\text { Contents }\end{array}$ \\
\hline 1 & Turbidity & NTU & 1 & BDL \\
\hline 2 & $\mathrm{Ph}$ & & 6.5 to 8.5 & 6.75 \\
\hline 3 & $\begin{array}{c}\text { Electrical } \\
\text { conductivity }\end{array}$ & Mhos/cm & & 93 \\
\hline 4 & Acidity & $\mathrm{mg} /$ litre & & 10 \\
\hline 5 & Alkalinity (Total) & $\mathrm{mg} /$ litre & 200 & 24 \\
\hline 6 & Sulphates & $\mathrm{mg} /$ litre & 200 & BDL \\
\hline 7 & $\begin{array}{l}\text { Total dissolved } \\
\text { solids }\end{array}$ & $\mathrm{mg} /$ litre & 500 & 43 \\
\hline 8 & Total hardness & $\mathrm{mg} /$ /itre & 200 & 30 \\
\hline 9 & Calcium & $\mathrm{mg} /$ litre & 75 & 8 \\
\hline 10 & Magnesium & $\mathrm{mg} /$ litre & 30 & 2.43 \\
\hline 11 & Chloride & $\mathrm{mg} /$ litre & 250 & 20 \\
\hline 12 & Fluoride & $\mathrm{mg} /$ litre & 1 & BDL \\
\hline 13 & Iron & $\mathrm{mg}$ /litre & 1 & 0.21 \\
\hline 14 & Nitrate & $\mathrm{mg} /$ litre & 45 & BDL \\
\hline 15 & Residual Chlorine & $\mathrm{mg} /$ /itre & 0.2 & 0 \\
\hline 16 & Coli forms & $\begin{array}{c}\text { No. of } \\
\text { coli } \\
\text { forms/ } \\
100 \mathrm{ml}\end{array}$ & 0 & Nil \\
\hline 17 & E-Coli & $\begin{array}{c}\text { No. of } \\
\text { coli } \\
\text { forms/ } \\
100 \mathrm{ml}\end{array}$ & 0 & Nil \\
\hline
\end{tabular}

From the test results of water quality analysis, it is observed that the pond water and water from tank is not suitable for drinking purpose. The water from the pond is highly contaminated with Coli form bacteria. Thus it may cause dangerous health problems if it is used without any proper treatment process. The test sample contain 1100 coli forms and $15 \mathrm{E}$-coli in pond water and 44 coli forms and 3 E-coli in water tank. The desirable limit of Coli form and E-coli bacteria is zero in cooler. . In this water test, lack of chlorination is observed from the analysis. For that, an additional of 875 gram of chlorine is added to the water tank by 2 weeks alternatively which is needed for the purification of water

2) Water quantity analysis TABLE IV. WATER QUANTITY ANALYSIS

\begin{tabular}{|c|c|c|c|c|}
\hline Activity & $\begin{array}{c}\text { Avg. } \\
\text { water } \\
\text { used per } \\
\text { activity } \\
\text { (litres) }\end{array}$ & $\begin{array}{c}\text { Activity } \\
\text { done by } \\
\text { each day }\end{array}$ & $\begin{array}{c}\text { No. of } \\
\text { person } \\
\text { using } \\
\text { water }\end{array}$ & $\begin{array}{c}\text { Total water } \\
\text { consumption } \\
\text { per day (litres) }\end{array}$ \\
\hline $\begin{array}{c}\text { Wash hand and } \\
\text { face }\end{array}$ & 1 & 2 & 942 & 1884 \\
\hline Bath & 80 & 1 & 56 & 4480 \\
\hline Toilet flush & 10 & 3 & 942 & 912 \\
\hline Drinking & 0.25 & 3 & 942 & 706.5 \\
\hline $\begin{array}{c}\text { Leakage of tap } \\
\text { (1 drop/sec/day) }\end{array}$ & 30 to 60 & & & 60 \\
\hline Cooking & \multicolumn{3}{|c}{} \\
\hline
\end{tabular}

From the observation, the total amount of water consumed per day is 42042.5 liters. Annually an amount of 15345512.5 liter water is needed.

\section{B Waste Audit}

1) Quantity of waste generated

The amounts of solid wastes generated in the Musaliar Institute are:

$>$ Biodegradable waste $=22 \mathrm{~kg} /$ day.

$>$ Non-biodegradable waste $=13 / 4 \mathrm{~kg} /$ day.

$>$ Hazardous wastes $=150$ grams/day.

2) Existing waste management methods

> Cleaning the campus on daily basis by the cleaning staffs.

$>$ Waste bins are placed in corridors, office and staff rooms.

$>$ A small scale biogas plant assembled in the men hostel area.

3) Observation

From the observation pollution from waste is aesthetically unpleasing and results in large amounts. In our campus the only way to manage waste is by waste sorting. For that increase the amount of waste bins the college.

\section{Energy Audit}

The energy auditing of the Musaliar Institute is mainly focused on the following factors:

$>$ The energy usage in the college. (Electricity, electric stove, kettle, microwave, LPG, firewood, Petrol, diesel and others).

$>$ Electricity bill amount of the previous years.

$>$ The CFL and LED bulbs installed in the institute (Hours used/day for how many days in a month).

$>$ The fans and air conditioners installed in the institute (Hours used/day for how many days in a month).

$>$ The computer and other equipment assembled in the college (Hours used/day for how many days in a month)

$>$ The energy saving invertors and batteries fixed (Hours used/day for how many days in a month).

$>$ The cooling apparatus installed in the college (Hours used/day for how many days in a month).

TABLE V. CALCULATION OF ENERGY FOR ELECTRICAL APPLIANCES

\begin{tabular}{|c|c|c|c|c|c|}
\hline Appliances & $\begin{array}{c}\text { Number } \\
\text { of } \\
\text { appliances }\end{array}$ & $\begin{array}{c}\text { Power } \\
\text { used } \\
\text { (Watt) }\end{array}$ & $\begin{array}{c}\text { Usage } \\
\text { per } \\
\text { day } \\
\text { (hr) }\end{array}$ & $\begin{array}{c}\text { Average } \\
\text { kWh } \\
\text { per day }\end{array}$ & $\begin{array}{c}\text { Average } \\
\text { kWh per } \\
\text { month }\end{array}$ \\
\hline Ac & 30 & 4000 & 2 & 240 & 7200 \\
\hline CC camera & 50 & 2 & 24 & 2.4 & 72 \\
\hline CFL & 368 & 40 & 2 & 29.44 & 883.2 \\
\hline $\begin{array}{c}\text { Computer } \\
\text { appliances }\end{array}$ & 202 & 175 & 2.5 & 88.37 & 2651.1 \\
\hline Fan & 636 & 75 & 7 & 333.9 & 10017 \\
\hline LED & 128 & 15 & 2 & 3.84 & 115.2 \\
\hline $\begin{array}{c}\text { Lab } \\
\text { equipments }\end{array}$ & 271 & 3 & 1.5 & 1.219 & 36.58 \\
\hline $\begin{array}{c}\text { Lab } \\
\text { equipments }\end{array}$ & 25 & 2500 & 1.5 & 93.75 & 2812.5 \\
\hline Projector & 28 & 300 & 1.5 & 12.6 & 378 \\
\hline $\begin{array}{c}\text { Water } \\
\text { cooler }\end{array}$ & 7 & 25 & 12 & 1.8 & 54 \\
\hline
\end{tabular}


The total energy utilization of the college for different purposes is $24170.98 \mathrm{kWh}$ units/month. The electricity charge of the institution per month is 136232. From the observation, it seems that increase in the usage of fans gives the highest charge of electricity.

\section{Biodiversity Mapping}

Biodiversity is the key indicator of the health of an ecosystem. The Musaliar campus protects aged old trees in addition to several new trees and plants planted. The campus is lush green with gardens, lawns, flowers and plants wherever there is open space and a wide variety of faunal species are presented. Also the rain water is collected in a specialized tank in the Administrative block in front of the college as a part of sustainability. There are 86 different species of plant are present in the college campus. Out of this plant species 49 of them are tress and 37 of them are herbs and shrubs. In this plant species 55 medicinal species, 38 fruit giving species, 70 flowering species, 55 non flowering species, 9 cash crops, 4 food crops and wood used species are presented. In the Musaliar campus there are approximately 1036 plants are presented.

1) Floral species

\section{TABLE VI. LIST OF PLANT SPECIES IDENTIFIED} DURING GREEN AUDITING

\begin{tabular}{|c|c|c|}
\hline $\begin{array}{l}\text { Serial } \\
\text { No. }\end{array}$ & Name of the plants & $\begin{array}{c}\begin{array}{c}\text { No. of each } \\
\text { species }\end{array} \\
\end{array}$ \\
\hline 1 & Abutilon hirtum & 12 \\
\hline 2 & Acacia penniervis & 12 \\
\hline 3 & Aegle marmelos & 31 \\
\hline 4 & Aegle marmelos & 6 \\
\hline 5 & Aerva lanata & 15 \\
\hline 6 & Allamanda cathartica & 17 \\
\hline 7 & Alocasia macrorrhiza & 128 \\
\hline 8 & Anacardium occidentale & 3 \\
\hline 9 & Araucaria heterophylla & 4 \\
\hline 10 & Artocarpus altilis & 15 \\
\hline 11 & Artocarpus heterophyllus & 18 \\
\hline 12 & Artocarpus hirsutus & 22 \\
\hline 13 & Asclepias curassavica & 11 \\
\hline 14 & Aucuba japonica & 21 \\
\hline 15 & Averrhoa & 3 \\
\hline 16 & Azadirachta indica & 17 \\
\hline 17 & Bauhinia variegate & 10 \\
\hline 18 & Bidens sulphurea & 8 \\
\hline 19 & Bixa orellana & 7 \\
\hline 20 & Bombax ceiba & 6 \\
\hline 21 & Bougainvillea & 8 \\
\hline 22 & Buxus sempervirens & 2 \\
\hline 23 & Caesalpinia sappan & 4 \\
\hline 24 & Caladium bicolour & 14 \\
\hline 25 & Carica papaya & 15 \\
\hline 26 & Cassia fistula & 7 \\
\hline 27 & Casuarina Equisetifolia & 14 \\
\hline 28 & Casuarina cunninghamiana & 3 \\
\hline 29 & Catheranthus rosea & 11 \\
\hline 30 & Chionanthud virginious & 16 \\
\hline 31 & Chrysothemis pulchella & 7 \\
\hline 32 & Cocos nucifera & 12 \\
\hline 33 & Codiaeum variegatum & 25 \\
\hline 34 & Cordyline fruticosa & 30 \\
\hline 35 & Couroupita guianensis & 1 \\
\hline 36 & Crinum moorei & 6 \\
\hline 37 & Cupaniopsis anacardioides & 4 \\
\hline 38 & Datura stramonium & 5 \\
\hline 39 & Delonix regia & 2 \\
\hline
\end{tabular}

\begin{tabular}{|c|c|c|}
\hline 40 & Dypsis lutescens & 43 \\
\hline 41 & Elaeocarpus sylvestris & 2 \\
\hline 42 & Erythrina abyssinica & 2 \\
\hline 43 & Erythrina variegate & 5 \\
\hline 44 & Euphorbia milii & 2 \\
\hline 45 & Excoecaria cochinchinensis & 16 \\
\hline 46 & Ficus benghalensis & 3 \\
\hline 47 & Ficus microcarpa & 5 \\
\hline 48 & Flacourtia jangomas & 1 \\
\hline 49 & Garcinia cowa & 2 \\
\hline 50 & Hevea brasiliensis & 10 \\
\hline 51 & Hibiscus rosa-sinensis & 9 \\
\hline 52 & Ixora coccinea & 18 \\
\hline 53 & Ligustrum lucidum & 6 \\
\hline 54 & Macaranga peltata & 25 \\
\hline 55 & Madhuca longifolia & 7 \\
\hline 56 & Mangifera indica & 20 \\
\hline 57 & Mentha piperita & 9 \\
\hline 58 & Mirabilis jalapa & 5 \\
\hline 59 & Morinda citrifolia & 7 \\
\hline 60 & Musa acuminate & 12 \\
\hline 61 & Nephelium lappaceum & 4 \\
\hline 66 & Nerium oleander & 4 \\
\hline 63 & Ocimum basilicum & 38 \\
\hline 64 & Ocimum tenuiflorum & 3 \\
\hline 65 & Ophiopogon jaburan & 6 \\
\hline 66 & Osmanthus fragrans & 2 \\
\hline 67 & Oxalis triangularis & 10 \\
\hline 68 & Paulownia tomentosa & 8 \\
\hline 69 & Phyllanthus emblica & 4 \\
\hline 70 & Polyscias scutellaria & 2 \\
\hline 71 & Pseuderanthemum carruthersii & 23 \\
\hline 72 & Psidium guajava & 5 \\
\hline 73 & Ruellia simplex & 9 \\
\hline 74 & Salix caprea & 1 \\
\hline 75 & Samanea saman & 18 \\
\hline 76 & Saraca asoca & 2 \\
\hline 77 & Schefflera arboricola & 16 \\
\hline 78 & Spathoglottis plicata & 18 \\
\hline 79 & Swietenia macrophylla & 18 \\
\hline 80 & Syzygium samarangense & 2 \\
\hline 81 & Tectona grandis & 22 \\
\hline 82 & Thespesia populnea & 5 \\
\hline 83 & Trachelospermum jasminoides & 25 \\
\hline 84 & Triphasia trifoliate & 15 \\
\hline 85 & Vetiveria zizanioides & 9 \\
\hline 86 & Vitex negundo & 5 \\
\hline
\end{tabular}

\section{2) Faunal species}

The campus consists of wide varieties of trees and plants which covered over a large area, such organism also present there. So that, it includes birds, spiders, reptiles, months, butterflies, insects, amphibians and other small organisms in large amount.

$\mathrm{E}$

Carbon Emission Evaluation

1) Calculation of emission

The emission is obtained by multiplying activity data for each category with the corresponding emission factor. The total emission factor can be calculated by adding up to the emission of each category.

TABLE VII. EMISSION FACTORS

\begin{tabular}{|c|c|}
\hline Parameters & Emission factors \\
\hline Human factor & 1.14 per person per day \\
\hline LPG & $1.5 \mathrm{~kg}$ per kg \\
\hline Building & 0.2 per sq. meter per year \\
\hline Electricity & 0.68956 per $\mathrm{kWh}$ \\
\hline Burning & $1.9 \mathrm{~kg}$ per $\mathrm{kg}$ \\
\hline Solid waste & $0.125 \mathrm{~kg}$ per kg \\
\hline
\end{tabular}


2) Analysis of carbon emission

$>$ Human Factor: Carbon dioxide emitted by a person per day is not negligible. It is equivalent to the emission of a car in a $5 \mathrm{~km}$ stretch. Just for breathing, humans emit per person each day 1000 grams of $\mathrm{CO}_{2}$, assuming that they cat normally and follow a mean diet of $2800 \mathrm{kCal}$. The population details of each zone include the total number of teaching faculty, non-teaching staff and students is 1041 at Musaliar institute. The carbon dioxide emissions will be larger in the Zone having highest population. The emissions are calculated by multiplying the human factor with respective carbon emission factor. Just for breathing, humans emit per person each day 1000 grms of $\mathrm{O}_{2}$, assuming that they ear normally and follow a mean diet of $2800 \mathrm{kcal}$.

TABLE VIII. DATA'S OF HUMAN BEING

\begin{tabular}{|r|c|c|c|}
\hline $\begin{array}{r}\text { Sl } \\
\text { No. }\end{array}$ & Category & Number & Total \\
\hline 1 & No. of students & 742 & \multirow{2}{*}{917} \\
\hline 2 & No. of teaching staff & 115 & \\
\hline 3 & No. of non teaching staff & 60 & \\
\hline
\end{tabular}

The total working hour of the college is 8 hours. Assume the number of hostellers as 80 . So about 961 persons are day scholars and they spent 8 hours in the college. The hostellers spent their 24 hours in the college campus. For calculating the carbon emission from human, assume the number of working days for students as 200 and for teaching faculties and non teaching staffs as 250 days in a year. Multiplying the number of humans by the number of working days in a year and the carbon emission factor for humans gives the carbon emission from humans in a year (1.14/person/day).

\section{TABLE VIII. CARBON EMISSION OF HUMAN BEINGS}

\begin{tabular}{|c|c|c|c|c|}
\hline $\begin{array}{c}\text { Sl } \\
\text { No. }\end{array}$ & Category & $\begin{array}{c}\text { No. of } \\
\text { working } \\
\text { hour }\end{array}$ & Number & $\begin{array}{c}\text { Carbon } \\
\text { emission } \\
\text { (kg CO } \mathbf{~ e )}\end{array}$ \\
\hline 1 & $\begin{array}{c}\text { No. of } \\
\text { students }\end{array}$ & 200 & 742 & 169176 \\
\hline 2 & $\begin{array}{c}\text { No. of } \\
\text { teaching staffs }\end{array}$ & \multirow{2}{*}{250} & 115 & \multirow{2}{*}{4} \\
\cline { 1 - 2 } & $\begin{array}{c}\text { No. of non } \\
\text { teaching staffs }\end{array}$ & & 60 & 49875 \\
\hline
\end{tabular}

Therefore, the total carbon emitted $=219351 \mathrm{~kg}$ $\mathrm{CO}_{2} \mathrm{e}$.

Dlectricity: Collect data on annual electricity bills. Find number of power units (In India, one unit= $1 \mathrm{kWh}$ of electricity) consumed in college from the monthly electricity bills issues by State Electricity Board/ Distribution/ Collection companies. Take monthly consumed units and then multiply them by 12 (No. of months in a year). Electricity consumption includes Lab, administrative block, internet facilities, staff room and class room and pumping of water. The monthly consumption of electricity is multiplied by the emission factor (0.689) will give the corresponding $\mathrm{CO}_{2}$ emission in Kilogram.

TABLE IX. DATA'S OF ELECTRICITY

\begin{tabular}{|c|c|c|}
\hline \multirow{2}{*}{ Month } & Electricity & \\
\cline { 2 - 3 } & Power (kWh) & Emissions $\mathbf{( k g ~ C O}_{\mathbf{2}} \mathbf{e}$ ) \\
\hline January & 9125 & 6287.125 \\
\hline February & 9345 & 6438.7 \\
\hline March & 9700 & 6686.3 \\
\hline April & 11650 & 8026.85 \\
\hline May & 9900 & 6821.1 \\
\hline June & 4700 & 3307.2 \\
\hline July & 4450 & 3066.05 \\
\hline August & 5450 & 3755.05 \\
\hline September & 6700 & 4616.3 \\
\hline October & 8525 & 5873.72 \\
\hline November & 8900 & 6063.2 \\
\hline December & 6750 & 4650.75 \\
\hline & 95195 & 65589.345 \\
\hline
\end{tabular}

LPG: The consumption of one litre of LPG can release $1.5 \mathrm{~kg}$ of carbon atmosphere. Each cylinder with a weight of $19.5 \mathrm{~kg}$. The consumption natural gas in canteen and hostel are surveyed. Gas cylinders of $19.5 \mathrm{~kg}$ are used. To find the carbon emission multiplies the total number of gas cylinders with the emission factor.

\section{TABLE X. LPG USED IN THE COLLEGE CAMPUS}

\begin{tabular}{|c|c|c|c|}
\hline $\begin{array}{c}\text { Sl } \\
\text { No. }\end{array}$ & $\begin{array}{c}\text { LPG used per } \\
\text { year }\end{array}$ & Number & Total \\
\hline 1 & Canteen & 24 & \multirow{2}{*}{124} \\
\hline 2 & Men's hostel & 96 & \\
\hline 3 & Labs & 4 & \\
\hline
\end{tabular}

Therefore, the carbon emission $=$ No. of gas cylinder x $19.5 \times 1.5=3627 \mathrm{~kg} \mathrm{CO}_{2} \mathrm{e}$

$>$ Burning Wood: About $1900 \mathrm{~g}$ carbon dioxide is released when burning of $1000 \mathrm{~g}$ of wood. The amount of wood used in Musaliar college canteen per year is 12 tones. The amount of wood used in Musaliar men's hostel per year is 30 tones. To find the carbon emission from burning wood, multiply the wood used in a year with the emission factor.

Carbon emission $=$ Wood used in a year $\mathrm{x}$ Emission factor $=79800 \mathrm{~kg} \mathrm{CO}_{2} \mathrm{e}$.

$>$ Buildings: It emit considerable amount of carbon dioxide into the atmosphere and add to the Carbon footprint. Continuous emissions are there from buildings. A square meter of brickwork produces $28 \mathrm{~kg}$ of carbon dioxide by the time it is delivered to site. The details of the total built up area of buildings and other structure are calculated and multiply with 0.2 provides the amount of carbon emission from buildings. 
TABLE XI. BUILDING DETAILS

\begin{tabular}{|c|c|}
\hline Building Name & $\begin{array}{c}\text { Area of each Building } \\
\left(\mathbf{m}^{\mathbf{2}} \mathbf{)}\right.\end{array}$ \\
\hline $\begin{array}{c}\text { Administrative Block } \\
\text { Lab }\end{array}$ & 2894 \\
\hline $\begin{array}{c}\text { Civil Engineering Block and Machine Tool } \\
\text { EEE and EC Block }\end{array}$ & 4041 \\
\hline Cultural Centre & 393.39 \\
\hline $\begin{array}{c}\text { Generator, Drivers, Security Cabins, Store, } \\
\text { Ladies rest rooms }\end{array}$ & 282.9 \\
\hline $\begin{array}{c}\text { Computer science Block } \\
\text { Mechanical, Hydraulic, Fluid, Electrical and } \\
\text { Mechanics Labs }\end{array}$ & 1810 \\
\hline Mechanical Engineering Block & 774.48 \\
\hline Placement Cell & 2887 \\
\hline MBA Block & 303.76 \\
\hline Total Area & 21364.53 \\
\hline
\end{tabular}

$>$ Solid Waste: In Indian conditions, about $0.5 \mathrm{~kg}$ to $1 \mathrm{~kg}$ of solid waste was generated by a person in a day. So we assume an average value $0.75 \mathrm{~kg}$ generation per day. Each kilogram of solid waste emits $0.125 \mathrm{~kg}$ of carbon. For calculating the carbon emission from solid waste from human activities, assume the number of working days for students as 200 and for teaching faculties and nonteaching staffs as 250 days in a year. About 0.125 $\mathrm{kg}$ of carbon is emitted from each $\mathrm{kg}$ of solid waste. Multiplying the number of humans by the number of working days in a year, amount of waste produced and the carbon emission factor for solid waste gives the carbon emissions.

Carbon emitted per year $=$ No. of humans $x$ No. of working day in a year $x$ Amount of waste produced $\mathrm{x}$ Carbon emission factor $=(742 \times 200 \mathrm{x}$ $0.25 \times 0.75)+(175 \times 250 \times 0.125 \times 0.75)=$ $(13912.5+4104.56)=18014.06 \mathrm{~kg} \mathrm{CO}_{2} \mathrm{e}$.

F Health audit

The health of the inhabitants shows the environmental stability of that area, it includes the availability of fresh air, water and a peaceful environment. Healthy and peaceful atmosphere is necessary for an educational institution. The physical and mental health problems may affect the overall performance of the college. To find out the health status of the campus, an online health survey is conducted by making questionnaires.

From this survey, it shows that there is no major health problems are found out and the students and staffs in the campus are mentally and physically stable.

\section{RECOMMENDATIONS}

1) Water audit

$>$ Remove damaged taps and install sensitive taps is possible.

$>$ For purification add 875 grams of chlorine should be added to the 3.5 lakhs liters water tank (for 1000 litters of water, 2.5 grams of chlorine is required).
$>$ Awareness programs on water conservation to be conducted.

2) Waste audit

$>$ Increase the usage of waste bins.

$>$ Establish a large scale bio gas plant.

$>$ Practice of waste segregation to be initiated.

$>$ A model Vermin composting plant to be set up in the college campus.

$>$ Establish a plastic free campus.

$>$ Avoid paper plates and cups for all functions in the college

3) Energy audit

$>$ The only way to decrease the electricity level of fan usage is turn off the appliance when not in use.

$>$ Energy saving through the replacement of incandescent bulbs, CFL lamps and tube lights to LED light by saving $552 \mathrm{kWh}$ per month.

$>$ Energy efficient electrical equipments especially fans and pump sets can be replaced against old ones.

$>$ Use computers and electronic equipments in power saving mode.

$>$ Install the production of solar energy a type of non-conventional category of energy will be a good energy management system for the college.

$>$ Awareness programs for the stakeholders to save energy may also increase sustainability in the utilization of various energy sources.

4) Biodiversity mapping

$>$ Proper arrangement of the plants in aesthetic way.

$>$ Grow potted plants at both verandas and fences.

$>$ Provide irrigation facility to the green area.

$>$ Not just celebrating environment day but making it a daily habit.

$>$ Beautify the college building with indoor plants.

$>$ Encouraging students not just through words, but through action for making the campus green

5) Carbon emission evaluation

$>$ Use biodegradable products for all kinds.

$>$ Use pressure cookers daily and fuel efficient cooking methods.

$>$ Avoid plastic and other non-biodegradable substance, which will reduce the carbon dioxide.

$>$ Eat low on the food chain.

$>$ Usage of vehicle with in the campus is very less. For short journeys either walk or cycle. And checkout diesel or petrol engine within the time period.

$>$ Choose organic and local foods that are in season.

$>$ Buy foodstuffs in bulk when possible using your own reusable container.

$>$ Compost your food waste if possible. 


\section{CONCLUSION}

$>$ The present environmental impacts at the Musaliar Institute is assess by the tool Green audit.

$>$ The surveys conducted at different target areas are evaluated and provide a management system.

$>$ The carbon emission evaluation gives the details about the sources of carbon and emission limit, whether it is a required limit or not.

$>$ The recommendations included in this report highlight many ways in which the college can work to improve its actions and become a more sustainable institution.

\section{REFERENCES}

[1] Andrew John, Vegetable industry carbon foot print scoping study- what is a Carbon foot print, Environmental Economics and Policy Studies, vol. 14, pp 13-141, 2018.
[2] Bhosale BB (Ph.D.), Green Audit a case study of K. J Somaiya College, Kopargaon, MS, India, Int. Res. J. of Science \& Engineering, 2018

[3] Dr Joshi Seema Pradip, Dr. Pavitra D. Patil, Green Audit- A Tool for attaining Sustainable Development \& Achieving Competitive Advantage, IBMRD's Journal of Management and Research, version 3, issue 1, March 2014.

[4] Gopa kumar, Greenhouse gas emission, Estimation and reduction India, Asian Productivity Organization, vol. 34, pp 87-125, 2019.

[5] Madhuri Pandit, Prof. Subhash B. Magar, Green Audit a case study of Art's, Science \& Commerce College, Manmad, IOSR Journal of Environmental Science, Toxicology and Food, Volume 9, Issue 8 Ver. I, Aug. 2015.

[6] Sangita Pradeep Ingole, Environmental Auditing: Its Benefits and Countenance, International Journal of Science Innovations and Discoveries, 2012.

[7] Sulakhe Prachi Pradiprao, Dr. A. C. Attar, Comparative study of Green Audits of different Educational Buildings, Journal NX- A Multidisciplinary Peer Reviewed Journal, ISSN No: 2581-4230, April 2018 